\title{
Localization of Neurotrophin Specific Trk Receptors in Mechanosensory Systems of Killifish (Nothobranchius guentheri)
}

\author{
Marialuisa Aragona ${ }^{+}\left(\mathbb{D}\right.$, Caterina Porcino ${ }^{\dagger}$, Maria Cristina Guerrera, Giuseppe Montalbano (D), Maria Levanti, \\ Francesco Abbate $(\mathbb{D}$, Rosaria Laurà and Antonino Germanà * $\mathbb{D}$
}

check for updates

Citation: Aragona, M.; Porcino, C.; Guerrera, M.C.; Montalbano, G.; Levanti, M.; Abbate, F.; Laurà, R.; Germanà, A. Localization of Neurotrophin Specific Trk Receptors in Mechanosensory Systems of Killifish (Nothobranchius guentheri). Int. J. Mol. Sci. 2021, 22, 10411. https://doi.org/10.3390/ ijms221910411

Academic Editor: Jan Kaslin

Received: 31 August 2021

Accepted: 24 September 2021

Published: 27 September 2021

Publisher's Note: MDPI stays neutral with regard to jurisdictional claims in published maps and institutional affiliations.

Copyright: (c) 2021 by the authors. Licensee MDPI, Basel, Switzerland. This article is an open access article distributed under the terms and conditions of the Creative Commons Attribution (CC BY) license (https:/ / creativecommons.org/licenses/by/ $4.0 /)$.
Zebrafish Neuromorphology Laboratory, Department of Veterinary Sciences, University of Messina, 98168 Messina, Italy; mlaragona@unime.it (M.A.); catporcino@unime.it (C.P.); mguerrera@unime.it (M.C.G.); gmontalbano@unime.it (G.M.); mblevanti@unime.it (M.L.); abbatef@unime.it (F.A.); laurar@unime.it (R.L.)

* Correspondence: agermana@unime.it

+ Both author contributed equally to this paper.

\begin{abstract}
Neurotrophins (NTs) and their signal-transducing Trk receptors play a crucial role in the development and maintenance of specific neuronal subpopulations in nervous and sensory systems. NTs are supposed to regulate two sensory systems in fish, the inner ear and the lateral line system (LLS). The latter is one of the major mechanosensory systems in fish. Considering that annual fishes of the genus Nothobranchius, with their short life expectancy, have become a suitable model for aging studies and that the occurrence and distribution of neurotrophin Trk receptors have never been investigated in the inner ear and LLS of killifish (Nothobranchius guentheri), our study aimed to investigate the localization of neurotrophin-specific Trk receptors in mechanosensory systems of N. guentheri. For histological and immunohistochemical analysis, adult specimens of N. guentheri were processed using antibodies against Trk receptors and S100 protein. An intense immunoreaction for TrkA and TrkC was found in the sensory cells of the inner ear as well as in the hair cells of LLS. Moreover, also the neurons localized in the acoustic ganglia displayed a specific immunoreaction for all Trk receptors (TrkA, B, and C) analyzed. Taken together, our results demonstrate, for the first time, that neurotrophins and their specific receptors could play a pivotal role in the biology of the sensory cells of the inner ear and LLS of N. guentheri and might also be involved in the hair cells regeneration process in normal and aged conditions.
\end{abstract}

Keywords: killifish; Nothobranchius guentheri; inner ear; lateral line system; free neuromast; neurotrophin; TrkA; TrkB; TrkC; S100 protein

\section{Introduction}

Mechanosensory systems in fish include the inner ear and lateral line system (LLS), forming together the acusticolateral system, also known as the octavolateralis system. As in mammals, in fish, the mechanosensory organs are under the control of the neurotrophins, a family of growth factor acting on different neuronal subpopulations in the central and peripheral nervous systems regulating neuronal proliferation, synaptic plasticity, development, survival, growth, and differentiation [1]. Neurotrophins' biological functions are mediated by signal-transducing systems that are initiated by their interactions with two kinds of receptors, the high-affinity Trk receptors (tyrosine kinase receptor) and the lowaffinity p75 neurotrophin receptor (p75NTR). The first are transmembrane tyrosine kinase proteins, known as TrkA, TrkB, and TrkC, interacting with their substrates in a specific but not exclusive way. TrkA binds the nerve growth factor (NGF), TrkB recognizes both brain-derived neurotrophic factor (BDNF) and neurotrophin-4 (NT-4), and TrkC interacts with neurotrophin-3 (NT-3). TrkA and TrkB can also bind, with a lower affinity, NT-3. On the other hand, the p75 receptor can bind to unprocessed or mature neurotrophin and act 
as Trks co-receptor [2]. Neurotrophins and their specific receptors are evolutionarily conserved and have been found, among other vertebrates, in fishes [3-7]. The genome of fishes contains two additional neurotrophins called neurotrophin-6 (NT-6) and neurotrophin-7 (NT-7) [8-10]. As in other vertebrates, neurotrophins and their specific receptors have been localized in the fish nervous system, including sensory organs. Particularly, the occurrence of neurotrophins was also demonstrated in fish inner ear and LLS [3,11-16]. Moreover, NTs and Trk receptors were also found in the zebrafish brain [17-21], retina [14,22], taste buds [23], and in the crypt neurons of the olfactory epithelium [24]. It was well demonstrated that the hair cells of fish inner ears and LLS neuromasts are, under a histological, anatomical, and molecular point of view, very similar to those present in the inner ear of higher vertebrates [25-27]. Moreover, unlike mammals, fish retain the capability of hair cells regeneration within few days after damage, including drug treatments with ototoxic antibiotics [28-30]. So, it is intriguing to understand the neurotrophins possible involvement in the regenerative process of the hair cells in fish in order to find ways of promoting sensory hair cell regeneration in humans [31]. Attention on sensory hair cell regeneration is raised because hair cell damage is one of the contributors to the most common form of hearing loss, sensorineural hearing loss (SNHL) [32-36]. One of these disease mechanisms could be due not only to the loss of inner hair cells (IHCs) but also to their IHC synapses, impaired synaptic transmission to spiral ganglion neurons (SGNs), and disrupted propagation of auditory information along the auditory nerve [37]. A form of sensorineural hearing loss is age-related hearing loss (AHL), whose prevalence is on the rise in industrialized society because of the increase in life expectancy [38]. Therefore we found it interesting to investigate the presence of neurotrophins and Trk-like proteins in the inner ear and lateral line in a model for aging studies, as a fish of Nothobranchius genus. Individuals of genus Nothobranchius are annual fishes living in East African ponds and popular in aquariums. They have a short life expectancy in the wild and captivity [39]. Because of its short life cycle, the Nothobranchius has become an intriguing and emergent experimental animal model in the aging investigation since the lack of short-lived models has hampered aging research in vertebrates [40]. Moreover, the ease of isolation of vertebrate aging-related genes by homology cloning makes Nothobranchius a suitable model to test manipulation on aging [41-43], together with inexpensive embryo storage and accelerated growth [44]. Particularly, two species of this genus have been studied: N. furzeri and N. guentheri. The first one has a maximum lifespan of only 3 months and offers the possibility to perform investigations thus far unthinkable in a vertebrate, such as drug screening with life-long pharmacological treatments and experimental evolution [45]. Similarly, the annual fish $N$. guentheri has a relatively short lifespan, is commercially available, easily reared in captivity and became a suitable model for aging studies [46,47]. Additionally, it offers a set of age-related biomarkers that can be employed to track the process of tissue aging $[48,49]$. For all the reasons mentioned above, the possible neurotrophins involvement in aging processes of the $N$. furzeri brain started to be explored. Therefore, the expression and localization of BDNF, NGF, and NT-4, NT- 6 and of their cognate receptors have been analysed in the Nothobranchius with a specific attention to the brain and retina [50-54]. We have undertaken this study in order to analyse the immunohistochemical distribution of the Trk receptors as well as of the S100 protein in the inner ear and lateral line of N. guentheri.

\section{Results}

\subsection{Histology}

The inner ear of N. guentheri includes three semicircular canals (anterior, horizontal, and posterior), the utricle, the saccule, and the lagena. The first one represents the vestibular system, and the last one is analogous to the mammalian cochlea. The saccule and the lagena are localized in a para-medial position relative to the central nervous system. Each semicircular canal has a dilated sac at the end, representing the ampulla, with a cluster of sensory cells corresponding to crista ampullaris (Figure 1a). This one shows a cuboidal epithelium. Hair, supporting, and basal cells are present, and they form the sensory 
epithelium in the apical part of the crista ampullaris (Figure 2c). Inside each ampulla, there is the sensory epithelium represented by the ampullary crest of the semicircular canals. It has an orientation perpendicular to the axis of the ampulla and to the canal to which it belongs. In the utricle, saccule, and lagena, the sensory epithelium is organized into macules with large otoliths (Figure 1b). The macula of the utricle shows horizontal orientation and detects static changes in the position of the head. The macules of the saccule and the lagena are placed vertically relative to the head. The VIII cranial nerve, the cochlear vestibule nerve, penetrates the ear and flows into the ganglia. After connecting to the ganglion, the vestibular nerve divides into an upper branch that innervates the hair cells of the utricle and the ampullae of the anterior and lateral semicircular canals. The lower branch innervates the saccule and the ampulla of the posterior semicircular canal (Figure 2b).

N. guentheri lateral line system is made up of free, superficial neuromasts that have been detected in the head and trunk. The cephalic lateral line system neuromasts of $N$. guentheri are present in the neurocranial bones located above the eye (supraorbital) and in the circumorbital bones below the eye (infraorbital and hyomandibular), on both sides of the head. Neuromasts run through in an embossed segment with incompletely ossified walls covered by a tympanic-like epithelium (insert Figure 3).

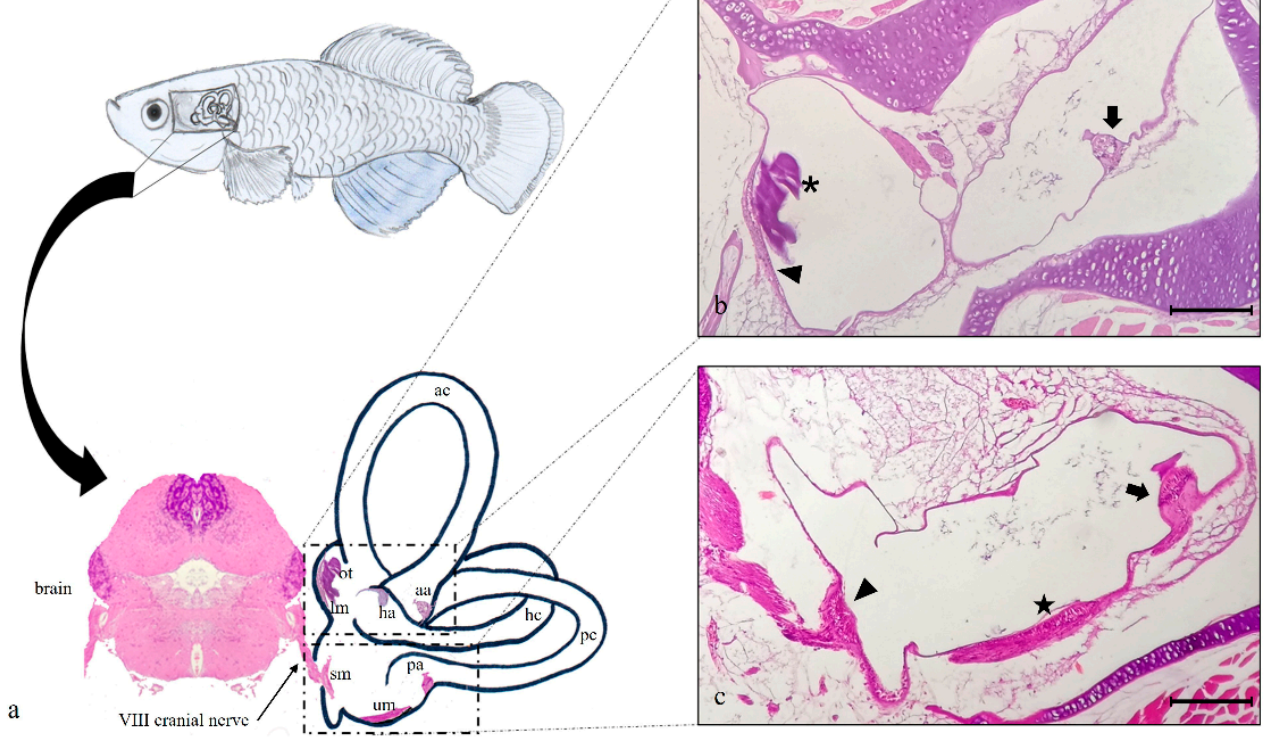

Figure 1. (a) graphical representation of N. guentheri inner ear that includes the three semicircular canals: anterior (ac), horizontal (hc), and posterior (pc) with their respective crista ampullaris (aa, ha, pa). Furthermore, the horizontal canal contains the macula of lagena (ml) and otholith (ot), while the posterior canal contains saccular macula (sm) and utricular macula (um). The brain from which branches off the $\mathrm{VIII}^{\circ}$ cranial nerve that innervates the saccular macula of the posterior canal in the inner ear is shown. (b) Light micrographs (H\&E): transversal view, the semicircular anterior canal (ac) of the inner ear, with crista ampullaris (arrow). Semicircular horizontal canal (hc) of the inner ear with macula of lagena (arrowhead) and otolith (asterisk). (c) Light micrographs (H\&E); transversal view, the semicircular posterior canal (pc) of the inner ear, with crista ampullaris (arrow), sacculus macula (arrowhead), and utricular macula (star). Magnification $10 \times(\mathbf{b}, \mathbf{c})$. Scale bars $200 \mu \mathrm{m}(\mathbf{b}, \mathbf{c})$. 


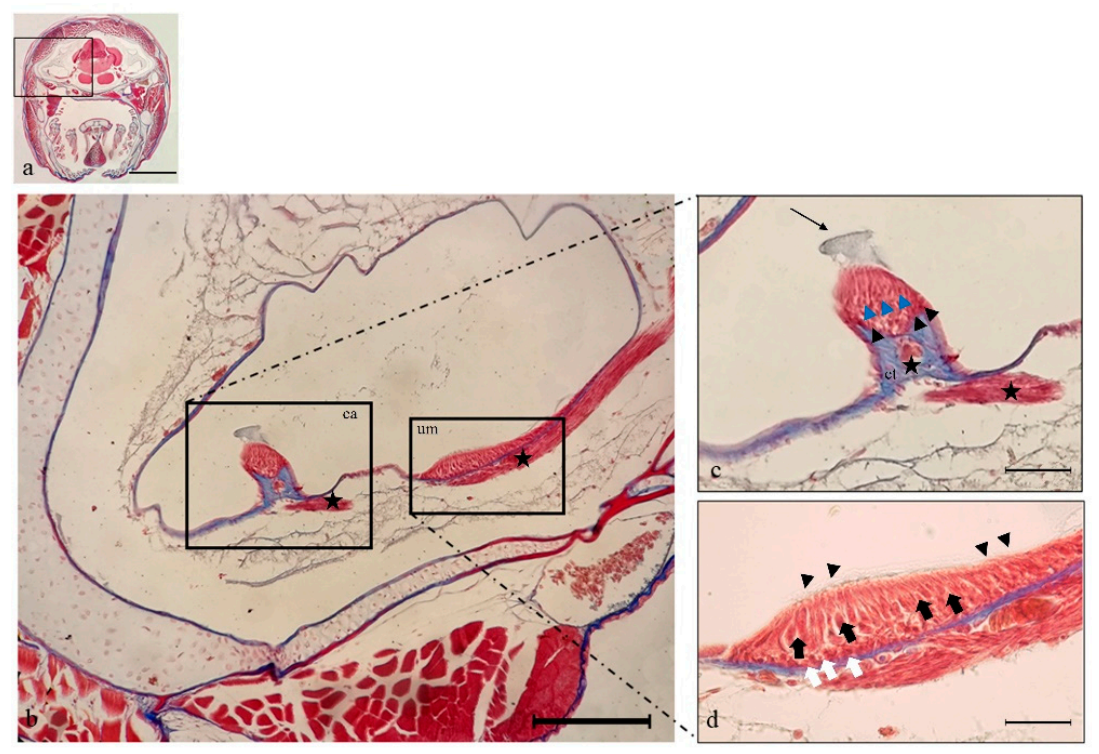

Figure 2. Light micrographs (Masson Trichrome with Aniline blue staining) of N. guentheri inner ear; transversal view. (a) Head. (b) Semicircular posterior canal of the inner ear, containing the crista ampullaris (ca) and the utricular macula (um). It is possible to observe the crista ampullaris innervation (star) and utricle macula innervation (star). (c) Higher magnification of crista ampullaris in the posterior canal: the connective tissue (ct) supports nerve fibers (star). The black arrowheads indicate the supporting cells, and blue arrowheads indicate the hair cells, the arrow points to the cupula. (d) Higher magnification of utricular macula. The portion of the utricle that forms the macula shows a sort of pouch. The sensory hair cells (black arrows) with numerous stereocilia (arrowheads) are visible. The white arrows indicate the supporting cells. Magnification $4 \times$, scale bar $1 \mathrm{~mm}$ (a). Magnification 10×, scale bar $200 \mu \mathrm{m}$ (b). Magnification $40 \times$, scale bar $50 \mu \mathrm{m}$ (c,d).

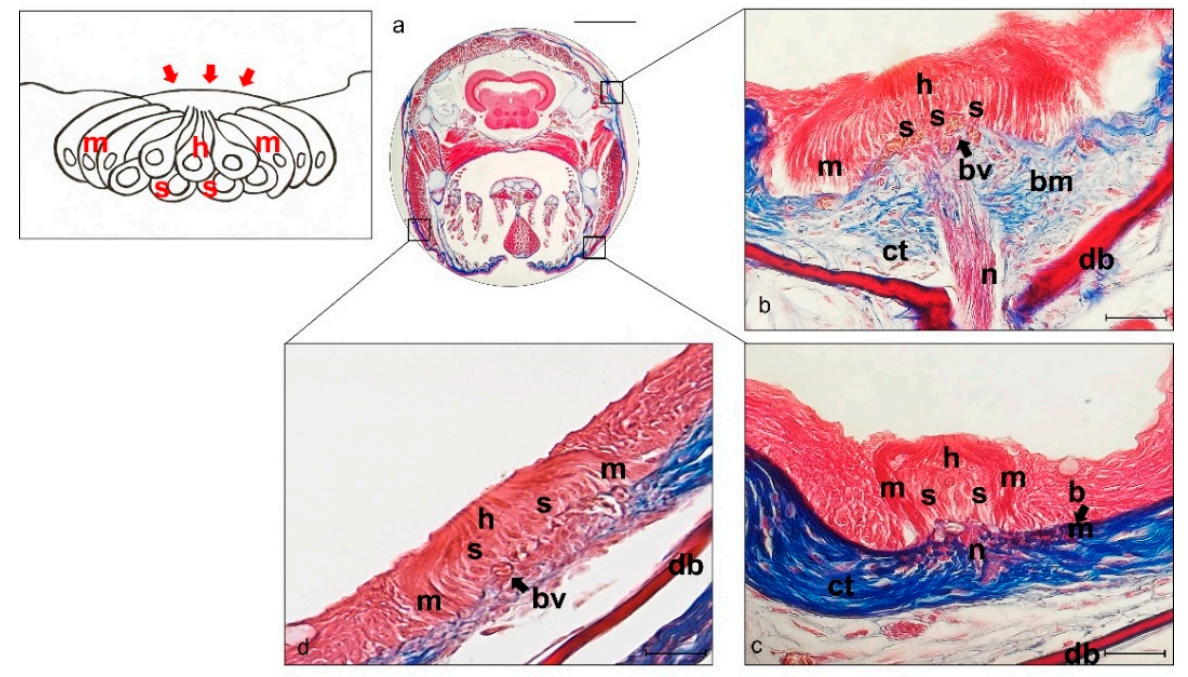

Figure 3. Light micrographs (Masson Trichrome with Aniline blue staining) (a-d) of lateral line system N. guentheri head; transversal view. (a) Head. (b) Supraorbital free neuromast. (c) Infraorbital free neuromast. (d) Iomandibular superficial free neuromast. (b-d). Free neuromast in N. guentheri head shows a group of hair sensory cells (h) supported by supporting cells (s) and surrounded laterally by long mantle cells (m). bv blood vessels, bm basal membrane, ct connective tissue, $\mathrm{n}$ nerve, db dermal bone. Magnification $4 \times$, scale bar $1 \mathrm{~mm}$ (a). Magnification $40 \times$, scale bar $50 \mu \mathrm{m}$ (b-d). The insert shows a graphical representation of free neuromast, and red arrows indicate tympanic-like epithelium. 
Superficial neuromasts located in the epidermis above the basement membrane were observed. The underlying dermal bone is present in the dermis. The walls of the bone canal ossify through the membrane and extend upwards from the underlying dermal bone on both sides of a neuromast (supraorbital neuromasts). These neuromasts are very large and show sensory cells surrounded by supporting and mantle cells (Figure 3b). The supporting cells are closely attached to the underlying connective, such as the mantle, to the epithelial cells. Different types of neuromasts are innervated by branches of the facial nerve: the supraorbital neuromasts are innervated by the superficial ophthalmic nerve, the infraorbital neuromasts by the buccal branch, the hyomandibular neuromasts by the hyomandibular branch.

The lateral line system of the trunk of $N$. guentheri shows small, superficial and free neuromasts running along the trunk. They show sensory hair cells, supporting cells, and mantle cells such as head neuromasts (Figure $4 a-c)$.
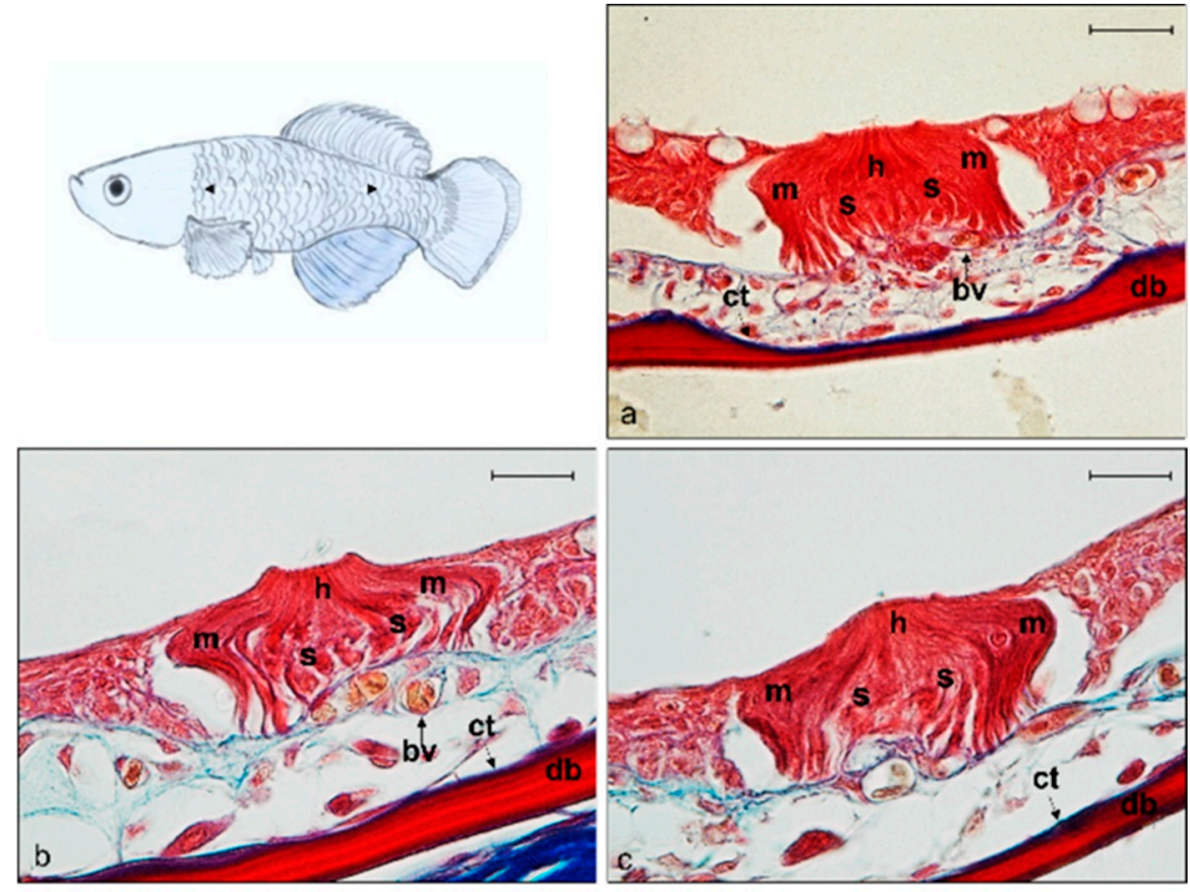

Figure 4. Light micrographs (Masson Trichrome with blue staining) (a-c) of lateral line system N. guentheri trunk; transversal view. Superficial free neuromast in N. guentheri trunk shows a group of hair sensory cells (h) supported by supporting cells (s) and surrounded laterally by long mantle cells (m). bv (arrow) blood vessels, bm basal membrane, ct (arrow) connective tissue, db dermal bone. Magnification $40 \times$, scale bar $50 \mu \mathrm{m}$.

\subsection{Immunohistochemistry}

Immunohistochemical analysis was carried out in serial sections using single and double immunofluorescence techniques. Cellular localization of Trks was performed in the inner ear and lateral line system of $N$. guentheri using monoclonal antibodies against TrkA and TrkB and a polyclonal antibody against TrkC. To identify the positive cells immune-marked with the antibodies we used, a morpho-topographical approach based on the observation of the cellular histological features was performed. The results, using confocal laser microscopy, demonstrated that TrkA and TrkC are present in the hair cells of the utricle macula (Figure 5a,b), saccule macula (Figure $5 \mathrm{~d}, \mathrm{e}$ ), and lagena macula (Figure $5 \mathrm{~g}, \mathrm{~h}$ ). Moreover, the immunohistochemical detection was performed in serial sections, with S100 protein utilized as a specific marker for hair cells. The TrkA and TrkC displayed a pattern of immune distribution like S100 protein, demonstrating the sensory origin of these cells (Figure $5 \mathrm{c}, \mathrm{f}, \mathrm{i})$. Both TrkA and TrkC were localized in the cytoplasm 
of cylindrical cells placed in the apical part of the sensory patches of the different macules (Figure 5a,b,d,e,g,h). These cells were identified as sensory hair cells because of their morphology and localization, as well as their S100 protein immunoreactivity (Figure 5c,f,i).
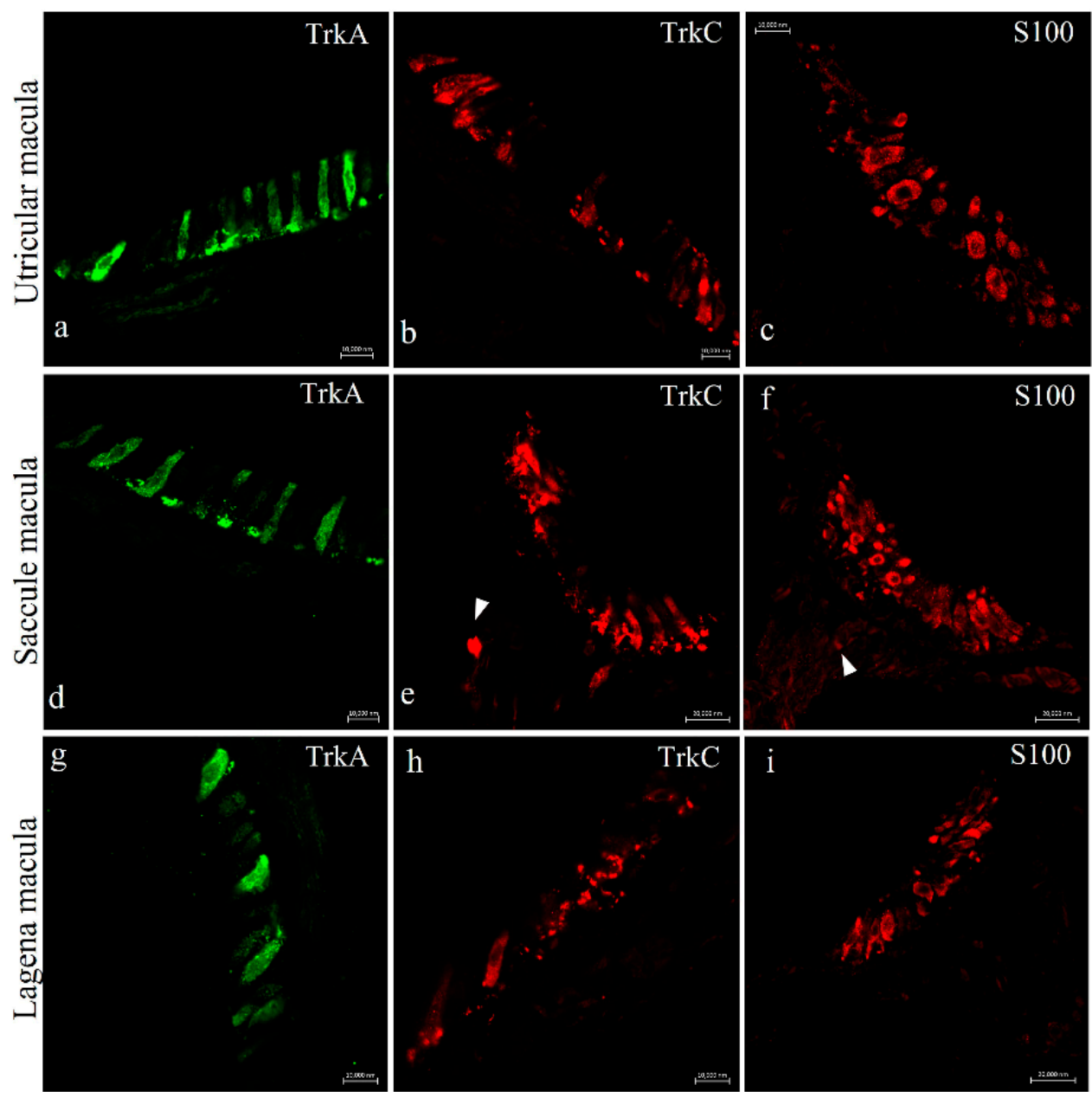

Figure 5. N.guentheri inner ear; transversal view. Immunohistochemical detection (immunofluorescence method) of Trka protein in the macula of the utricle (a), saccule (d), and lagena (g), of Trkc in the macula of the utricle (b), saccule (e), and lagena (h). Immunohistochemical detection of S100 protein in the macula of the utricle (c), saccule (f), and lagena (i). The utricular and saccular maculae consist of cylindrical epithelium formed by sensory hair, supporting, mantle and basal cells. Cytoplasmatic immunoreactivity for these antibodies was found in the sensory epithelial cells of the utriculus, sacculus, and lagena. Arrowheads (e,f) indicate nerves. Magnification $63 \times(\mathbf{a}-\mathbf{d}, \mathbf{g}, \mathbf{h}) ; 40 \times(\mathbf{e}, \mathbf{f}, \mathbf{i})$.

An immunoreactivity for TrkA, TrkC, and S100 proteins was detected in the cristae ampullaris of the semicircular canals. In a subpopulation of hair cells, specific staining was respectively detected in the central and peripheral parts of the sensory cell cluster (Figure 6a-c). 
TrkA

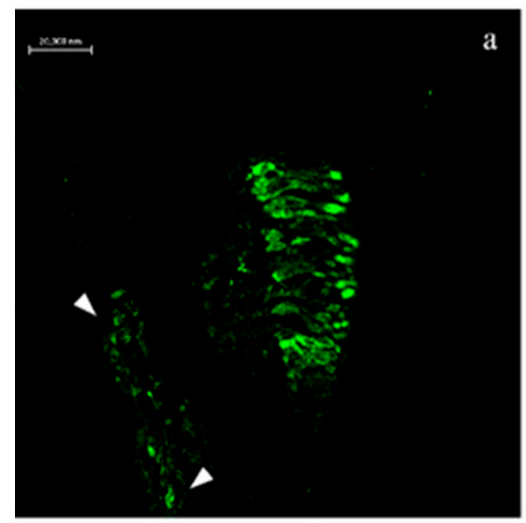

TrkC

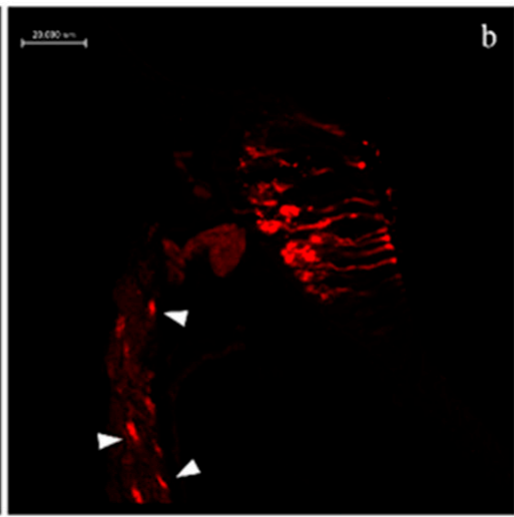

S100

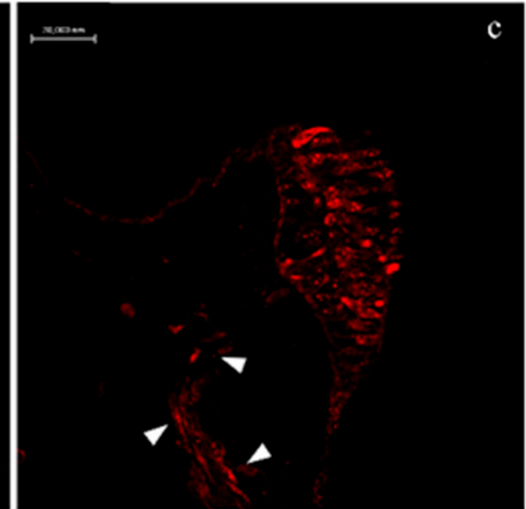

Figure 6. N.guentheri inner ear; transversal view. Immunohistochemical detection (immunofluorescence method) of TrkA (a), TrkC (b), and S100 protein (c) in sensory hair cells of the cristae ampullaris. The cristae ampullaris in the apical portion contain sensory hair cells, supporting cells, and basal cells. Arrowheads (a-c) indicate nerves. Magnification $40 \times$.

The results obtained with confocal immunofluorescence displayed that TrkA, TrkC, and s100 antibody marked cells were located in the central-apical portion of the neuromasts, corresponding to hair cells (Figure 7a-s). Specific staining to this antibody in sensory hair cells was found in supraorbital (Figure 7a-f), infraorbital (Figure 7g-i,1-n), and hyomandibular (Figure 7o-s) of the head.
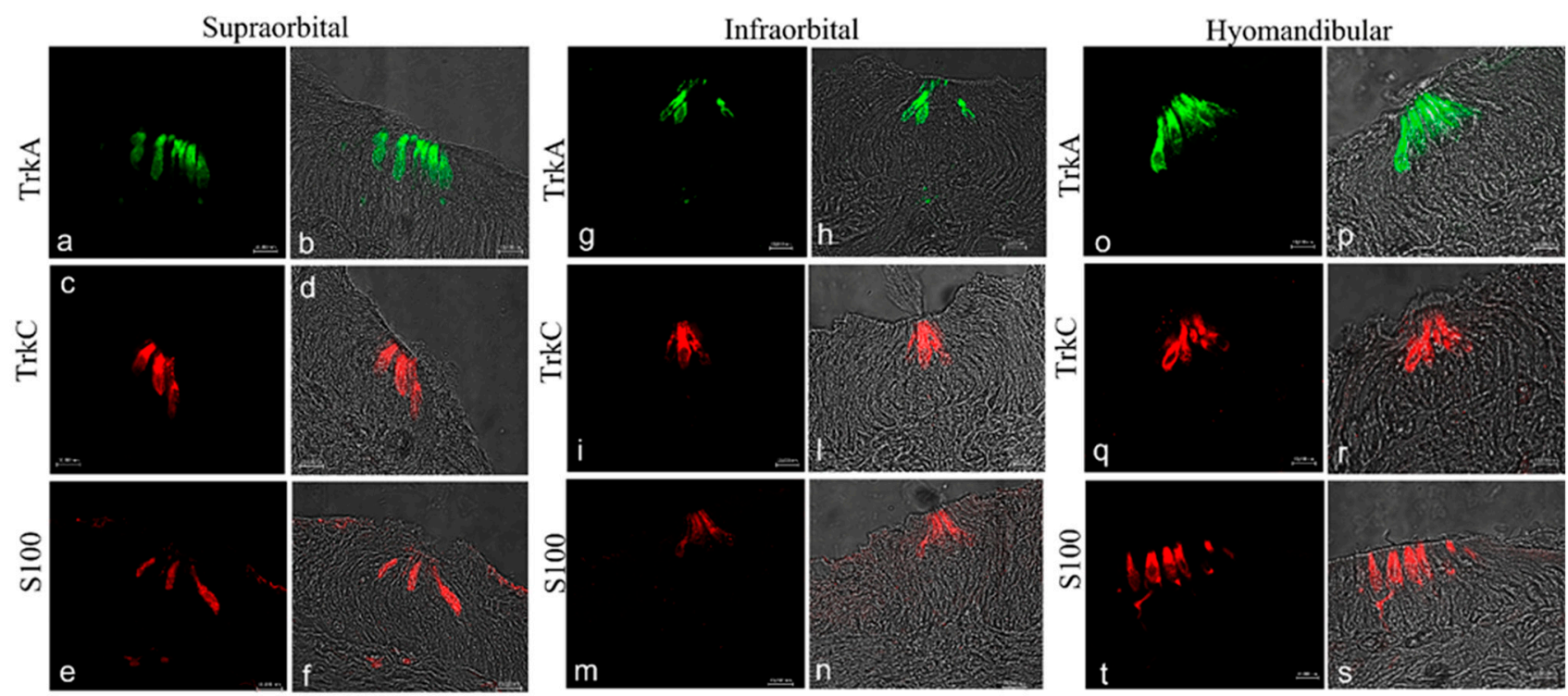

Figure 7. Lateral line system of N. guentheri head; transversal view. Immunohistochemical detection (immunofluorescence method) of TrkA, TrkC, and S100 protein. Supraorbital (a-f), infraorbital $(\mathbf{g}-\mathbf{i}, \mathbf{l}-\mathbf{n})$, and iomandibular free neuromast $(\mathbf{o}-\mathbf{t})$ in $N$. guentheri head show a group of sensory hair cells supported by supporting cells and laterally surrounded by long mantle cells. The hair cells in supraorbital, infraorbital, and hyomandibular free neuromast displayed cytoplasmatic immunoreactivity for TrkA, TrkC, and S100 protein. Magnification $40 \times$.

Moreover, ganglia of the VIII cranial nerve showed an intense and specific immunoreactivity for TrkA (Figure 8b,e), TrkB (Figure 9b,e), TrkC (Figures 8a and 9d) as well as S100 protein (Figures $8 \mathrm{~d}$ and $9 \mathrm{a}$ ). No immunoreaction for TrkB receptor was found in any structure of the inner ear and lateral line system of N. guentheri, with particular attention to the neuroepithelium. 

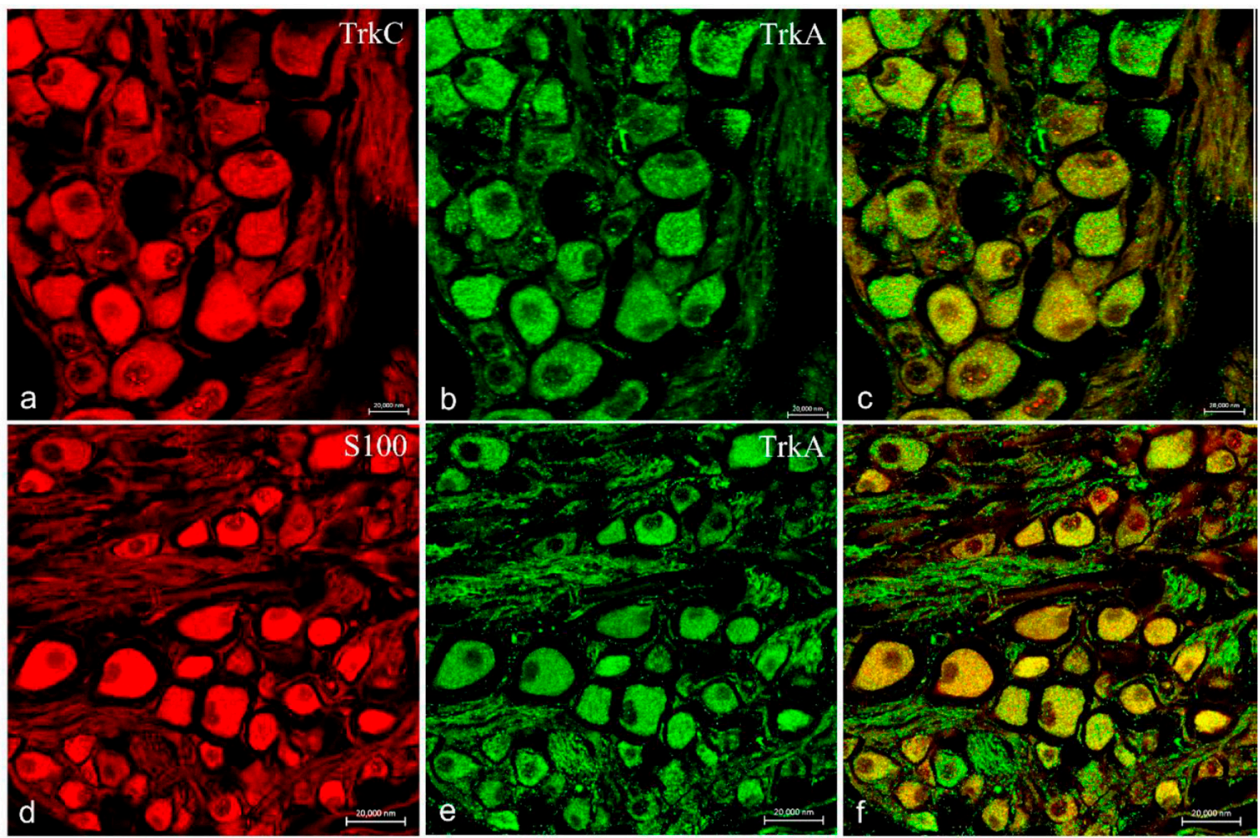

Figure 8. Ganglia of the VIII cranial nerve of N. guentheri head; transversal view. Immunohistochemical detection (immunofluorescence method) of trkA, trkC, and S100 protein. Immunoreactivity displayed to TrkA (b,e), TrkC (a), and S100 (d). Colocalization view (c,f) Magnification 40×.
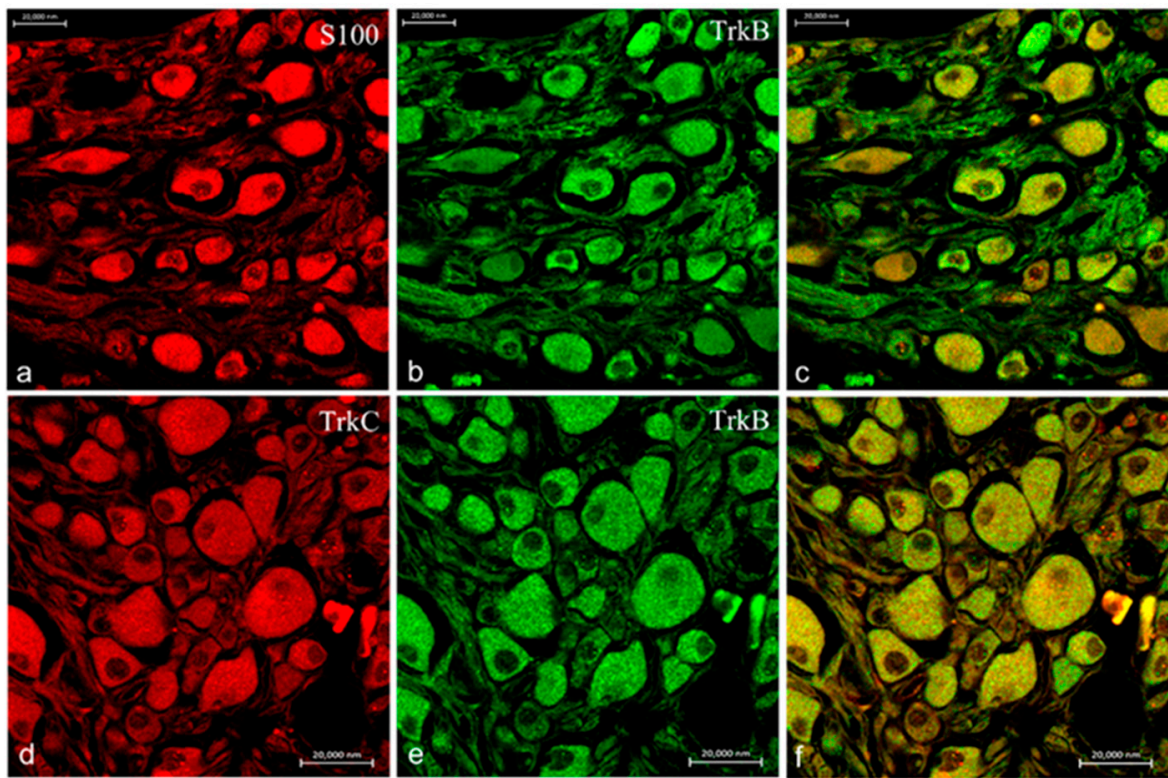

Figure 9. Ganglia of the VIII cranial nerve of N. guentheri head; transversal view. Immunohistochemical detection (immunofluorescence method) of TrkB, TrkC, and S100 protein. Immunoreactivity displayed to $\operatorname{TrkB}(\mathbf{b}, \mathbf{e}), \operatorname{TrkC}(\mathbf{d})$, and S100 (a). Colocalization view (c,f). Magnification 40×.

\section{Discussion}

The Nothobranchius became an intriguing and emergent experimental animal model in the aging investigation due to its short lifespan cycle. For this unique characteristic, these fish are considered a sort of bridge between mouse and Caenorhabditis elegans, representing two models widely utilized in biomedicine research. Specifically, the mouse is phylogenetically similar to humans but has a long life expectancy, and C. elegans has a short life span but is less close to us in evolutionary terms [40]. Moreover, the Nothobrachius represents a good model for inexpensive embryo storage, accelerated growth, and expression of aging 
histological and behavioral biomarkers, and easy isolation of vertebrate aging-related genes by homology cloning [45]. Nothobranchius is a suitable model to test manipulation on aging and study the evolution of aging-related genes by testing the effects of natural selection. Particularly, two species of this genus have been studied: N. furzeri and N. guentheri. The first one has a maximum lifespan of only 3 months and offers the possibility to perform investigations thus far unthinkable in a vertebrate, such as a drug screening with life-long pharmacological treatments and experimental evolution [45]. Similarly, the annual fish $N$. guentheri has a relatively short lifespan, is commercially available, is easily reared in captivity, and has become a suitable model for aging studies [46,47]. Additionally, it offers a set of age-related biomarkers that can be employed to track the process of tissue aging $[48,49]$. In this study, we demonstrate for the first time the localization of Trk receptor proteins in the inner ear and lateral line system of N. guentheri. Moreover, in this research report, the S100 protein was used to identify the sensory cells present in the mechanoreceptor organs. S100 proteins are a large subfamily of EF-hand $\mathrm{Ca}^{2+}$-binding proteins localized in the cytoplasm and/or nucleus of a wide range of cells, participating in the regulation of intracellular $\mathrm{Ca}^{2+}$ homeostasis as a trigger or activator proteins. This protein was previously utilized in zebrafish as a specific marker for hair cells of the inner ear sensory patches and sensory cells of lateral line neuromast [23,55-58]. Moreover, the S100 protein expression has been demonstrated in the glial cells and neurons of zebrafish and different areas of $N$. furzeri central nervous system [51,59]. In this investigation, the localization of neurotrophin-specific Trk receptors was observed in the sensory cells of the killifish mechanosensory systems made up of the inner ear and lateral line system (LLS). In fish, the lateral line system consists of superficial neuromasts (SN) and canal neuromasts $(\mathrm{CN})$, partially deriving from the neural crest [60]. The lateral line system can significantly diversify between different fish species, and the distribution of $\mathrm{SN}$ and $\mathrm{CN}$ shows a high degree of variability among these animals. Surface-feeding fishes detect surface waves caused by distressed insects that have fallen into the water with their cephalic LLS [61,62]. This could be in line with our results, demonstrating bigger neuromasts in the cephalic lateral line system than trunk LLS neuromasts in N. guentheri. The latter are innervated by the vagus lateral branch [63]. Finally, our results demonstrate that in N. guentheri, LLS is made up of free and superficial neuromasts lifetime and not only during larval and juvenile stages such as in other species (e.g., zebrafish).

Particularly, we found a specific immunoreaction for TrkA and TrkC in the hair cells of the macula of the utricle, saccule, and lagena, in the crista ampullaris of the inner ear and the central cluster of hair cells of lateral line neuromasts. It is well known that neurotrophins and their specific Trk receptors are required for neuronal survival of the central and peripheral nervous system, including sensory organs $[14,22-24,56,64]$ and that the neurotrophins sequence is well conserved during evolution with an origin of the Trk family dated approximately 600 million years ago $[4,65]$. The specificity of the antibodies used was previously tested and demonstrated in the brain of N. furzeri using Dot-blot analysis and immunohistochemistry [51]. The obtained results of this report are in agreement with previous studies performed in different species of fish, including zebrafish (Danio rerio), sea bass (Dicentrarchus labrax), salmon (Salmo salar), and trout (Salmo trutta) regarding the localization of Trk receptors in the hair cells of mechanoreceptor tissue of fish auditory systems $[11-14,16]$. In recent papers from our group of investigation, the expression and localization of BDNF/TrkB system in the lateral line and inner ear of zebrafish were showed [15]. In contrast, in this study, no immunoreaction for BDNF and TrkB was observed in the hair cells of $N$. guentheri. A specific and intense immunoreaction for TrkB was found in the neurons of the acoustic ganglia demonstrating the presence of the BDNF/TrkB system in Nothobranchius, but not in the mechanoreceptor organs. This discrepancy might be due to a different regulation system of the biology of sensory cells in the short lifespan fish and could also be related to the short life cycle of the fish characterized by the rapidly changing of the protein expression of the sensory cells during the physiological process of hair cell regeneration. 
It is well demonstrated that the neurotrophin family plays an important role in the synaptic plasticity of sensory hair cells. Particularly, the BDNF/TrkB and NT-3/TrkC systems exert a specific and important function in the regulation of the auditory system in mammals [66], supporting the maintenance of the spiral ganglion neurons in culture and suggesting their potential therapeutic use as a novel drug in sensory hearing loss disorders [67]. Mammals have a limited capacity to regenerate cells and tissue, and this activity decreases sharply during aging. In mammals, the capability to regenerate inner ear hair cells is very restricted or absent. Therefore, the loss of sensory cells in humans leads to a wide range of inner ear disorders with a permanent reduction of hearing and balance. In this way, our results demonstrate, for the first time, that also the sensory cells of the inner ear and lateral line system of N. guentheri, as previously observed in zebrafish $[15,68,69]$, are very similar, from a morpho-physiological point of view, to human sensory cells. Moreover, fishes maintain the possibility to regenerate the hair cells following damage caused by a traumatic event, intense acoustic stimuli, environmental insults, and pharmacological or ototoxic chemicals treatment. Specifically, it has been well demonstrated, using zebrafish transgenic line, that the lateral line sensory cells can regenerate under experimental conditions within few days, completely restoring their functional activities $[28,29,31,70-78]$. Our results are in line with the hypothesis that neurotrophins and their receptors may play a role in the regeneration process; indeed, we observe an immunopositivity to Trks receptors in the hair cells of the LLS neuromasts and of the inner ear. For this reason, the fish auditory system and especially the mechanoreceptor organs of Nothobranchius for the characteristic of short life cycle might represent an excellent model to deeply analyze the molecular events linked to the regeneration process that might represent a cardinal point in the study of aging inner ear disorders.

In N. guentheri, the presence of TrkA and TrkC in the sensory cells of the macula as well as of the crista and in the neuromast of the lateral line system might suggest a key function of NGF and NT-3 in the complex mechanism of sensory organs homeostasis in the annual fish, such as in mammals [66]. Moreover, the presence of NGF, NT-4, and NT-6 was detected in the brain of $N$. furzeri $[52,79,80]$, where the authors hypothesize that the NGF/TrkA system could modulate several physiological functions in the adult brain of $N$. furzeri, playing a role during aging processes. Finally, based on the obtained results, we can assume that the Nothobranchius could represent a suitable model to study age-related hearing loss studies continuing to investigate the role of growth factors in the biology of sensory cells within the sensory patches of sensory organs.

\section{Materials and Methods}

\subsection{Fish and Tissue Treatment}

In this study, we used adult specimens of $N$. guentheri found dead by unknown causes (1-year-old, 1 male, and 2 females) in ornamental aquariums (freshwater, $22^{\circ} \mathrm{C}, \mathrm{pH} 6.8-7.0$ ). The heads were quickly removed, fixed in $4 \%$ paraformaldehyde in phosphate-buffered saline (PBS) (AAJ19943K2, Thermo Scientific) $0.1 \mathrm{~m}(\mathrm{pH}=7.4)$ for $12-18 \mathrm{~h}$, dehydrated through graded ethanol series, and clarified in xylene for paraffin wax embedding. Included tissues were then cut into $7 \mu \mathrm{m}$ thick serial sections and collected on gelatin-coated microscope slides. Then, serial sections were deparaffinized and rehydrated, washed in distilled water, and stained with hematoxylin and eosin (H\&E) (Carazzi's Hematoxylin Nuclear staining, 05-M06012; Eosin Y 1\% aqueous solution cytoplasmic staining, 05-M10002, Bio-Optica Milano s.p.a.) and Masson Trichrome with aniline blue method (04-010802, Bio-Optica Milano s.p.a.). Sections were examined under a Leica DMRB light microscope.

\subsection{Localization of TrkS and S100 Protein Using Single and Double Immunofluorescence Staining}

To analyze the expression of different proteins in the sensory patches of the inner ear, lateral line system, and the acoustic ganglia, sections were deparaffinized and rehydrated, washed in Phosphate-Buffered Saline (PBS) $0.1 \mathrm{M} \mathrm{pH}=7.4$, and incubated in $0.3 \% \mathrm{H}_{2} \mathrm{O}_{2}$ (PBS) solution for $3 \mathrm{~min}$ to prevent the activity of endogenous peroxidase; then fetal bovine 
serum (F7524 Sigma-Aldrich) was added to rinsed sections. Sections were incubated overnight at $4{ }^{\circ} \mathrm{C}$ in a humid chamber with antibodies anti-Trks and anti S100 protein that recognizes a mixture of both $\mathrm{s} 100 \mathrm{~A}$ and s100B proteins subunit (see Table 1). Moreover, to analyze the expression of different proteins in acoustic ganglia, TrkA and TrkB monoclonal antibodies were used in double-label experiments with polyclonal antibodies TrkC and S100 (see Table 1).

Table 1. Primary Antibodies.

\begin{tabular}{cccccc}
\hline Primary Antibodies & Supplier & Catalogue Number & Source & Diluition & Antibody ID \\
\hline S100 & Dako & Z0311 & rabbit & $1: 100$ & AB_10013383 \\
\hline TrkA (Y32Ex) & Santa Cruz Biotechnology, Inc. & sc-80398 & mouse & $1: 100$ & AB_1130726 \\
\hline TrkB (F-1) & Santa Cruz Biotechnology, Inc. & sc-377218 & mouse & $1: 100$ & AB_2801499 \\
\hline TrkC (798) & Santa Cruz Biotechnology, Inc. & sc-117 & rabbit & $1: 100$ & AB_632560 \\
\hline
\end{tabular}

After rinsing in PBS, the sections were incubated for $1 \mathrm{~h}$ at $4{ }^{\circ} \mathrm{C}$ with anti-Mouse IgG $(\mathrm{H}+\mathrm{L})$ Alexa Fluor 488 (Invitrogen, Waltham, MA, USA; catalog number A-21202; diluted 1:300) and anti-Rabbit IgG $(\mathrm{H}+\mathrm{L})$ Alexa Fluor 568 (Invitrogen, USA; catalog number A-21207; diluted 1:300). Both steps were performed at room temperature in a dark, humid chamber. Finally, the sections were washed, dehydrated, and mounted with Fluoromount Aqueous Mounting Medium (Sigma Aldrich, St. Louis, MO, USA). The immunofluorescence was detected using a Zeiss LSMDUO confocal laser scanning microscope with META module (Carl Zeiss MicroImaging GmbH, Göttingen, Germany), and the captured images were processed using Zen 2011 (LSM 700 Zeiss software). Each image was rapidly acquired to minimize photodegradation. Digital images were cropped, and the figure montage was prepared using Adobe Photoshop 7.0 (Adobe Systems, San Jose, CA, USA). To provide negative controls, representative sections were incubated with specifically preabsorbed antisera as described above. Under these conditions, no positive immunostaining was observed (data not shown).

Author Contributions: Conceptualization, A.G.; methodology, M.A., C.P., M.C.G., investigation, A.G., M.L., C.P., M.C.G.; writing-original draft preparation, M.L., C.P., A.G.; writing-review and editing, F.A., R.L., M.L.; supervision, A.G., R.L., F.A., M.L.; funding acquisition, A.G. and G.M. All authors have read and agreed to the published version of the manuscript.

Funding: This research was funded by FFABR—2020 Prof. Antonino Germanà funding by University of Messina.

Data Availability Statement: All data presented this study are available from the corresponding author, upon responsible request.

Conflicts of Interest: The authors declare no conflict of interest.

\section{References}

1. Henderson:, C.E. Role of neurotrophic factors in neuronal development. Curr. Opin. Neurobiol. 1996, 6, 64-70. [CrossRef]

2. Chao, M.V. Neurotrophins and their receptors: A convergence point for many signalling pathways. Nat. Rev. Neurosci. 2003, 4, 299-309. [CrossRef]

3. Hallböök, F. Evolution of the vertebrate neurotrophin and Trk receptor gene families. Curr. Opin. Neurobiol. 1999, 9, 616-621. [CrossRef]

4. Heinrich, G.; Lum, T. Fish neurotrophins and Trk receptors. Int. J. Dev. Neurosci. 2000, 18, 1-27. [CrossRef]

5. Martin, S.C.; Marazzi, G.; Sandell, J.H.; Heinrich, G. Five Trk Receptors in the Zebrafish. Dev. Biol. 1995, 169, 745-758. [CrossRef]

6. Caminos, E.; Becker, E.; Martín-Zanca, D.; Vecino, E. Neurotrophins and their receptors in the tench retina during optic nerve regeneration. J. Comp. Neurol. 1999, 404, 321-331. [CrossRef]

7. García-Suárez, O.; Germanà, A.; Hannestad, J.; Pérez-Pérez, M.; Esteban, I.; J Naves, F.; Vega, J.A. Changes in the expression of the nerve growth factor receptors TrkA and p75LNGR in the rat thymus with ageing and increased nerve growth factor plasma levels. Cell Tissue Res. 2000, 301, 225-234. [CrossRef] 
8. Götz, R.; Köster, R.; Winkler, C.; Raulf, F.; Lottspeich, F.; Schartl, M.; Thoenen, H. Neurotrophin-6 is a new member of the nerve growth factor family. Nature 1994, 372, 266. [CrossRef]

9. Nilsson, A.-S.; Fainzilber, M.; Falck, P.; Ibáñez, C.F. Neurotrophin-7: A novel member of the neurotrophin family from the zebrafish. FEBS Lett. 1998, 424, 285-290. [CrossRef]

10. Lai, K.-O.; Fu, W.-Y.; Ip, F.C.F.; Ip, N.Y. Cloning and Expression of a Novel Neurotrophin, NT-7, from Carp. Mol. Cell. Neurosci. 1998, 11, 64-76. [CrossRef]

11. Hannestad, J.; Marino, F.; Germanà, A.; Catania, S.; Abbate, F.; Ciriaco, E.; Vega, J. Trk neurotrophin receptor-like proteins in the teleost Dicentrarchus labrax. Cell Tissue Res. 2000, 300, 1-9. [CrossRef]

12. Catania, S.; Germana, A.; Cabo, R.; Ochoa-Erena, F.; Guerrera, M.; Hannestad, J.; Represa, J.; Vega, J. Neurotrophin and Trk neurotrophin receptors in the inner ear of Salmo salar and Salmo trutta. J. Anat. 2007, 210, 78-88. [CrossRef]

13. Germanà, A.; Sánchez-Ramos, C.; Guerrera, M.C.; Calavia, M.; Navarro, M.; Zichichi, R.; García-Suárez, O.; Pérez-Piñera, P.; Vega, J.A. Expression and cell localization of brain-derived neurotrophic factor and TrkB during zebrafish retinal development. J. Anat. 2010, 217, 214-222. [CrossRef]

14. Germanà, A.; Laurà, R.; Montalbano, G.; Guerrera, M.C.; Amato, V.; Zichichi, R.; Campo, S.; Ciriaco, E.; Vega, J.A. Expression of Brain-Derived Neurotrophic Factor and TrkB in the Lateral Line System of Zebrafish During Development. Cell. Mol. Neurobiol. 2010, 30, 787-793. [CrossRef]

15. Germanà, A.; Guerrera, M.C.; Laurà, R.; Levanti, M.; Aragona, M.; Mhalhel, K.; Germanà, G.; Montalbano, G.; Abbate, F. Expression and Localization of BDNF/TrkB System in the Zebrafish Inner Ear. Int. J. Mol. Sci. 2020, 21, 5787. [CrossRef]

16. Germana, A.; Catania, S.; Cavallaro, M.; González-Martínez, T.; Ciriaco, E.; Hannestad, J.; Vega, J.A. Immunohistochemical localization of BDNF-, TrkB- and TrkA-like proteins in the teleost lateral line system. J. Anat. 2002, 200, 477-485. [CrossRef]

17. Lucini, C.; D'Angelo, L.; Cacialli, P.; Palladino, A.; De Girolamo, P. BDNF, Brain, and Regeneration: Insights from Zebrafish. Int. J. Mol. Sci. 2018, 19, 3155. [CrossRef]

18. Montalbano, G.; Mania, M.; Guerrera, M.C.; Abbate, F.; Laurà, R.; Navarra, M.; Vega, J.A.; Ciriaco, E.; Germanà, A. Morphological differences in adipose tissue and changes in BDNF/Trkb expression in brain and gut of a diet induced obese zebrafish model. Ann. Anat.-Anat. Anz. 2016, 204, 36-44. [CrossRef]

19. Cacialli, P.; Gueguen, M.-M.; Coumailleau, P.; D'Angelo, L.; Kah, O.; Lucini, C.; Pellegrini, E. BDNF expression in larval and adult zebrafish brain: Distribution and cell identification. PLoS ONE 2016, 11, e0158057. [CrossRef]

20. De Felice, E.; Porreca, I.; Alleva, E.; De Girolamo, P.; Ambrosino, C.; Ciriaco, E.; Germanà, A.; Sordino, P. Localization of BDNF expression in the developing brain of zebrafish. J. Anat. 2014, 224, 564-574. [CrossRef]

21. Abbate, F.; Guerrera, M.C.; Montalbano, G.; Levanti, M.B.; Germanà, G.P.; Navarra, M.; Laurà, R.; Vega, J.A.; Ciriaco, E.; Germanà, A. Expression and anatomical distribution of TrkB in the encephalon of the adult zebrafish (Danio rerio). Neurosci. Lett. 2014, 563, 66-69. [CrossRef]

22. Sánchez-Ramos, C.; Bonnin-Arias, C.; Guerrera, M.C.; Calavia, M.G.; Chamorro, E.; Montalbano, G.; López-Velasco, S.; LópezMuñiz, A.; Germanà, A.; Vega, J.A. Light regulates the expression of the BDNF/TrkB system in the adult Zebrafish retina. Microsc. Res. Tech. 2013, 76, 42-49. [CrossRef]

23. Germana, A.; Montalbano, G.; Laura, R.; Ciriaco, E.; Del Valle, M.; Vega, J.A. S100 protein-like immunoreactivity in the crypt olfactory neurons of the adult zebrafish. Neurosci. Lett. 2004, 371, 196-198. [CrossRef]

24. Catania, S.; Germana, A.; Laura, R.; Gonzalez-Martinez, T.; Ciriaco, E.; Vega, J. The crypt neurons in the olfactory epithelium of the adult zebrafish express TrkA-like immunoreactivity. Neurosci. Lett. 2003, 350, 5-8. [CrossRef]

25. Brignull, H.R.; Raible, D.W.; Stone, J.S. Feathers and fins: Non-mammalian models for hair cell regeneration. Brain Res. 2009, 1277, 12-23. [CrossRef]

26. Esterberg, R.; Coffin, A.B.; Ou, H.; Simon, J.A.; Raible, D.W.; Rubel, E.W. Fish in a dish: Drug discovery for hearing habilitation. Drug Discov. Today: Dis. Models 2013, 10, e23-e29. [CrossRef]

27. Thomas, E.D.; Cruz, I.A.; Hailey, D.W.; Raible, D.W. There and back again: Development and regeneration of the zebrafish lateral line system. Wiley Interdiscip. Rev. Dev. Biol. 2015, 4, 1-16. [CrossRef]

28. Montalbano, G.; Capillo, G.; Laurà, R.; Abbate, F.; Levanti, M.; Guerrera, M.; Ciriaco, E.; Germanà, A. Neuromast hair cells retain the capacity of regeneration during heavy metal exposure. Ann. Anat.-Anat. Anz. 2018, 218, 183-189. [CrossRef]

29. Montalbano, G.; Abbate, F.; Levanti, M.B.; Germanà, G.P.; Laurà, R.; Ciriaco, E.; Vega, J.A.; Germanà, A. Topographical and drug specific sensitivity of hair cells of the zebrafish larvae to aminoglycoside-induced toxicity. Ann. Anat.-Anat. Anz. 2014, 196, 236-240. [CrossRef]

30. Montalbano, G.; Maugeri, A.; Guerrera, M.C.; Miceli, N.; Navarra, M.; Barreca, D.; Cirmi, S.; Germanà, A. A white grape juice extract reduces fat accumulation through the modulation of ghrelin and leptin expression in an in vivo model of overfed zebrafish. Molecules 2021, 26, 1119. [CrossRef]

31. Monroe, J.D.; Rajadinakaran, G.; Smith, M.E. Sensory hair cell death and regeneration in fishes. Front. Cell. Neurosci. 2015, 9, 131. [CrossRef]

32. Cruickshanks, K.J.; Wiley, T.L.; Tweed, T.S.; Klein, B.E.; Klein, R.; Mares-Perlman, J.A.; Nondahl, D.M. Prevalence of hearing loss in older adults in Beaver Dam, Wisconsin: The epidemiology of hearing loss study. Am. J. Epidemiol. 1998, 148, 879-886. [CrossRef] 
33. Cruickshanks, K.J.; Tweed, T.S.; Wiley, T.L.; Klein, B.E.; Klein, R.; Chappell, R.; Nondahl, D.M.; Dalton, D.S. The 5-year incidence and progression of hearing loss: The epidemiology of hearing loss study. Arch. Otolaryngol.-Head Neck Surg. 2003, 129, $1041-1046$. [CrossRef]

34. Liberman, M.C.; Kiang, N.Y. Acoustic trauma in cats: Cochlear pathology and auditory-nerve activity. Acta Oto-Laryngol. 1978.

35. Mcgill, T.J.; Schuknecht, H.F. Human cochlear changes in noise induced hearing loss. Laryngoscope 1976, 86, 1293-1302. [CrossRef]

36. Schuknecht, H.F.; Gacek, M.R. Cochlear pathology in presbycusis. Ann. Otol. Rhinol. Laryngol. 1993, 102, 1-16. [CrossRef]

37. Moser, T.; Starr, A. Auditory neuropathy—neural and synaptic mechanisms. Nat. Rev. Neurol. 2016, 12, 135-149. [CrossRef]

38. Liberman, M.C.; Kujawa, S.G. Cochlear synaptopathy in acquired sensorineural hearing loss: Manifestations and mechanisms. Hear. Res. 2017, 349, 138-147. [CrossRef]

39. Cellerino, A.; Valenzano, D.R.; Reichard, M. From the bush to the bench: The annual Nothobranchius fishes as a new model system in biology. Biol. Rev. 2016, 91, 511-533. [CrossRef]

40. Lucas-Sánchez, A.; Almaida-Pagán, P.F.; Mendiola, P.; de Costa, J. Nothobranchius as a model for aging studies. A review. Aging Dis 2013, 5, 281-291. [CrossRef]

41. Valenzano, D.R.; Sharp, S.; Brunet, A. Transposon-mediated transgenesis in the short-lived African killifish Nothobranchius furzeri, a vertebrate model for aging. G3 Genes Genomes Genet. 2011, 1, 531-538. [CrossRef]

42. Hartmann, N.; Englert, C. A microinjection protocol for the generation of transgenic killifish (Species: Nothobranchius furzeri). Dev. Dyn. 2012, 241, 1133-1141. [CrossRef]

43. Petzold, A.; Reichwald, K.; Groth, M.; Taudien, S.; Hartmann, N.; Priebe, S.; Shagin, D.; Englert, C.; Platzer, M. The transcript catalogue of the short-lived fish Nothobranchius furzeri provides insights into age-dependent changes of mRNA levels. BMC Genom. 2013, 14, 185. [CrossRef]

44. Tozzini, E.T.; Cellerino, A. Nothobranchius annual killifishes. EvoDevo 2020, 11, 1-9. [CrossRef]

45. Genade, T.; Benedetti, M.; Terzibasi, E.; Roncaglia, P.; Valenzano, D.R.; Cattaneo, A.; Cellerino, A. Annual fishes of the genus Nothobranchius as a model system for aging research. Aging Cell 2005, 4, 223-233. [CrossRef]

46. Hsu, C.-Y.; Chiu, Y.-C. Ambient temperature influences aging in an annual fish (Nothobranchius rachovii). Aging Cell 2009, 8, 726-737. [CrossRef]

47. Valenzano, D.R.; Cellerino, A. Resveratrol and the Pharmacology of Aging: A New Vertebrate Model to Validate an Old Molecule. Cell Cycle 2006, 5, 1027-1032. [CrossRef]

48. Liu, C.; Wang, X.; Feng, W.; Li, G.; Su, F.; Zhang, S. Differential expression of aging biomarkers at different life stages of the annual fish Nothobranchius guentheri. Biogerontology 2012, 13, 501-510. [CrossRef]

49. Wang, X.; Shang, X.; Luan, J.; Zhang, S. Identification, expression and function of apolipoprotein E in annual fish Nothobranchius guentheri: Implication for an aging marker. Biogerontology 2014, 15, 233-243. [CrossRef]

50. D'Angelo, L.; De Girolamo, P.; Lucini, C.; Terzibasi, E.T.; Baumgart, M.; Castaldo, L.; Cellerino, A. Brain-derived neurotrophic factor: mRNA expression and protein distribution in the brain of the teleost Nothobranchius furzeri. J. Comp. Neurol. 2014, 522, 1004-1030. [CrossRef]

51. D'Angelo, L.; de Girolamo, P.; Cellerino, A.; Tozzini, E.T.; Castaldo, L.; Lucini, C. Neurotrophin Trk receptors in the brain of a teleost fish, Nothobranchius furzeri. Microsc. Res. Tech. 2012, 75, 81-88. [CrossRef]

52. Leggieri, A.; Attanasio, C.; Palladino, A.; Cellerino, A.; Lucini, C.; Paolucci, M.; Terzibasi Tozzini, E.; de Girolamo, P.; D’Angelo, L. Identification and expression of neurotrophin-6 in the brain of Nothobranchius furzeri: One more piece in neurotrophin research. J. Clin. Med. 2019, 8, 595. [CrossRef]

53. D'angelo, L. Brain Atlas of an Emerging Teleostean Model: Nothobranchius furzeri. Anat. Rec. 2013, 296, 681-691. [CrossRef]

54. D'Angelo, L.; Lossi, L.; Merighi, A.; de Girolamo, P. Anatomical features for the adequate choice of experimental animal models in biomedicine: I. Fishes. Ann. Anat.-Anat. Anz. 2016, 205, 75-84. [CrossRef]

55. Abbate, F.; Catania, S.; Germana, A.; González, T.; Diaz-Esnal, B.; Germana, G.; Vega, J. S-100 protein is a selective marker for sensory hair cells of the lateral line system in teleosts. Neurosci. Lett. 2002, 329, 133-136. [CrossRef]

56. Germana, A.; González-Martínez, T.; Catania, S.; Laura, R.; Cobo, J.; Ciriaco, E.; Vega, J. Neurotrophin receptors in taste buds of adult zebrafish (Danio rerio). Neurosci. Lett. 2004, 354, 189-192. [CrossRef]

57. Germanà, A.; Paruta, S.; Germanà, G.P.; Ochoa-Erena, F.J.; Montalbano, G.; Cobo, J.; Vega, J.A. Differential distribution of S100 protein and calretinin in mechanosensory and chemosensory cells of adult zebrafish (Danio rerio). Brain Res. 2007, 1162, 48-55. [CrossRef]

58. Montalbano, G.; Mania, M.; Guerrera, M.C.; Laurà, R.; Abbate, F.; Levanti, M.; Maugeri, A.; Germanà, A.; Navarra, M. Effects of a Flavonoid-Rich Extract from Citrus sinensis Juice on a Diet-Induced Obese Zebrafish. Int. J. Mol. Sci. 2019, 20, 5116. [CrossRef]

59. Germanà, A.; Marino, F.; Guerrera, M.C.; Campo, S.; de Girolamo, P.; Montalbano, G.; Germanà, G.P.; Ochoa-Erena, F.J.; Ciriaco, E.; Vega, J.A. Expression and distribution of S100 protein in the nervous system of the adult zebrafish (Danio rerio). Microsc. Res. Tech. 2008, 71, 248-255. [CrossRef]

60. Collazo, A.; Fraser, S.E.; Mabee, P.M. A dual embryonic origin for vertebrate mechanoreceptors. Science 1994, $264,426-430$. [CrossRef] [PubMed]

61. Schwartz, E. Ferntastsinnesorgane von Oberflächenfischen. Z. Für Morphol. Der Tiere 1970, 67, 40-57. [CrossRef]

62. Hoin-Radkovsky, I.; Bleckmann, H.; Schwartz, E. Determination of source distance in the surface-feeding fish Pantodon buchholzi Pantodontidae. Anim. Behav. 1984, 32, 840-851. [CrossRef] 
63. Edgley, D.E.; Genner, M.J. Adaptive Diversification of the Lateral Line System during Cichlid Fish Radiation. iScience 2019, 16, 1-11. [CrossRef]

64. Germana, A.; Abbate, F.; González-Martínez, T.; Del Valle, M.; De Carlos, F.; Germanà, G.; Vega, J. S100 protein is a useful and specific marker for hair cells of the lateral line system in postembryonic zebrafish. Neurosci. Lett. 2004, 365, 186-189. [CrossRef]

65. Beck, G.; Munno, D.W.; Levy, Z.; Dissel, H.M.; Van-Minnen, J.; Syed, N.I.; Fainzilber, M. Neurotrophic activities of trk receptors conserved over 600 million years of evolution. J. Neurobiol. 2004, 60, 12-20. [CrossRef] [PubMed]

66. Fritzsch, B.; Tessarollo, L.; Coppola, E.; Reichardt, L.F. Neurotrophins in the ear: Their roles in sensory neuron survival and fiber guidance. In Progress in Brain Research; Elsevier: Amsterdam, The Netherlands, 2004; Volume 146, pp. $265-278$.

67. Szobota, S.; Mathur, P.D.; Siegel, S.; Black, K.; Saragovi, H.U.; Foster, A.C. BDNF, NT-3 and Trk receptor agonist monoclonal antibodies promote neuron survival, neurite extension, and synapse restoration in rat cochlea ex vivo models relevant for hidden hearing loss. PLoS ONE 2019, 14, e0224022. [CrossRef] [PubMed]

68. Bang, P.I.; Sewell, W.F.; Malicki, J.J. Morphology and cell type heterogeneities of the inner ear epithelia in adult and juvenile zebrafish (Danio rerio). J. Compart. Neurol. 2001, 438, 173-190. [CrossRef] [PubMed]

69. Laurà, R.; Abbate, F.; Germanà, G.; Montalbano, G.; Germanà, A.; Levanti, M. Fine structure of the canal neuromasts of the lateral line system in the adult zebrafish. Anat. Histol. Embryol. 2018, 47, 322-329. [CrossRef] [PubMed]

70. Chen, Y.; Zhang, S.; Chai, R.; Li, H. Hair Cell Regeneration. In Hearing Loss: Mechanisms, Prevention and Cure; Springer: Berlin/Heidelberg, Germany, 2019; pp. 1-16. [CrossRef]

71. Coffin, A.B.; Ramcharitar, J. Chemical ototoxicity of the fish inner ear and lateral line. In Fish Hearing and Bioacoustics; Springer: Berlin/Heidelberg, Germany, 2016; Volume 877, pp. 419-437.

72. Stawicki, T.M.; Esterberg, R.; Hailey, D.W.; Raible, D.W.; Rubel, E.W. Using the zebrafish lateral line to uncover novel mechanisms of action and prevention in drug-induced hair cell death. Front. Cell. Neurosci. 2015, 9, 46. [CrossRef]

73. Harris, J.A.; Cheng, A.G.; Cunningham, L.L.; MacDonald, G.; Raible, D.W.; Rubel, E.W. Neomycin-induced hair cell death and rapid regeneration in the lateral line of zebrafish (Danio rerio). J. Assoc. Res. Otolaryngol. 2003, 4, 219-234. [CrossRef]

74. Volpe, B.A.; Fotino, T.H.; Steiner, A.B. Confocal Microscope-Based Laser Ablation and Regeneration Assay in Zebrafish Interneuromast Cells. J. Vis. Exp. JoVE 2020. [CrossRef]

75. Germanà, A.; Montalbano, G.; Guerrera, M.C.; Laura, R.; Levanti, M.; Abbate, F.; de Carlos, F.; Vega, J.A.; Ciriaco, E. Sox-2 in taste bud and lateral line system of zebrafish during development. Neurosci. Lett. 2009, 467, 36-39. [CrossRef]

76. Pinto-Teixeira, F.; Viader-Llargués, O.; Torres-Mejía, E.; Turan, M.; González-Gualda, E.; Pola-Morell, L.; López-Schier, H. Inexhaustible hair-cell regeneration in young and aged zebrafish. Biol. Open 2015, 4, 903-909. [CrossRef]

77. Cruz, I.A. Adult Zebrafish Lateral Line: A Well Supported System. 2015. Available online: http://hdl.handle.net/1773/34063 (accessed on 24 September 2021).

78. López-Schier, H.; Hudspeth, A. A two-step mechanism underlies the planar polarization of regenerating sensory hair cells. Proc. Natl. Acad. Sci. USA 2006, 103, 18615-18620. [CrossRef] [PubMed]

79. D'Angelo, L.; Castaldo, L.; Cellerino, A.; de Girolamo, P.; Lucini, C. Nerve growth factor in the adult brain of a teleostean model for aging research: Nothobranchius furzeri. Ann. Anat.-Anat. Anz. 2014, 196, 183-191. [CrossRef] [PubMed]

80. D'Angelo, L.; Avallone, L.; Cellerino, A.; de Girolamo, P.; Paolucci, M.; Varricchio, E.; Lucini, C. Neurotrophin-4 in the brain of adult Nothobranchius furzeri. Ann. Anat.-Anat. Anz. 2016, 207, 47-54. [CrossRef] [PubMed] 